\title{
Central Neurogenic Hyperventilation Secondary to a Critic Thyroid Status after Aortoaortic Bypass: A Peculiar Case Report
}

\author{
Ana Belén Fernández \\ Department of Anesthesiology and Critical Care Unit, Ntra Sra de Candelaria University Hospital, Santa Cruz de Tenerife, Spain \\ Email: anabfp@gmail.com
}

How to cite this paper: Fernández, A.B. (2017) Central Neurogenic Hyperventilation Secondary to a Critic Thyroid Status after Aortoaortic Bypass: A Peculiar Case Report. Open Journal of Anesthesiology, 7, 130-133.

https://doi.org/10.4236/ojanes.2017.75013

Received: April 18, 2017

Accepted: May 22, 2017

Published: May 25, 2017

Copyright $\odot 2017$ by author and Scientific Research Publishing Inc. This work is licensed under the Creative Commons Attribution International License (CC BY 4.0).

http://creativecommons.org/licenses/by/4.0/

\begin{abstract}
Central neurogenic hyperventilation $(\mathrm{CNH})$ is a rare condition and defined as a syndrome comprising normal or elevated arterial oxygen tension, decreased arterial carbon dioxide tension, respiratory alkalosis with hyperventilation even during sleep, and the absence of a peripheral respiratory stimulus. The diagnosis of $\mathrm{CNH}$ requires the exclusion of pulmonary, cardiac, metabolicimmunological disorders and some medicines that can result in hyperventilation. We detailed the case of $\mathrm{CNH}$ in the $4^{\text {th }}$ day after vascular surgery probably secondary to acute metabolic acidosis with hyperlactatemia, due to severe hypothyroidism in the context of critically ill patient.
\end{abstract}

\section{Keywords}

Lactic Acidosis, Metabolic Acidosis, Myxedema Coma, Central Neurogenic Hyperventilation

\section{Introduction}

Central neurogenic hyperventilation $(\mathrm{CNH})$ was defined for the first time by Plum and Swanson in 1959 as a syndrome with decrease in $\mathrm{PaCO}_{2}$, increase in $\mathrm{PaO}_{2}$ and respiratory alkalosis with no other clinical or radiological feature of pulmonary disorder and usually results from lesions in the medial pontine tegmentum and disruption of cortical inhibitory effects of the medullar respiratory center [1].

The main causes of hyperventilation are: pulmonary embolism, severe asthma attack, pneumothorax, myocardial ischemia, congestive heart failure, hyperthyroidism, pheochromocytoma, alcohol and drugs, severe metabolic acidosis, fever, acute pain, ischemia and traumatism. Even if most of $\mathrm{CNH}$ are caused by 
CNS tumours, especially lymphomas, invasion of brain tissue may produce tissue acidosis and develop hyperventilation [2] [3] [4].

In our literature research we found 8 cases of postsurgical CNH: 5 of them were after the third endoscopic ventriculostomy, 1 after anaplastic astrocytoma resection and 2 after general anesthesia in non-neurosurgical procedures [5][12].

\section{Case Report}

We report a case of a 63-year-old man scheduled for elective aortoaortic bypass graft surgery due to a $70 \mathrm{~mm}$ aortic aneurysm. The patient suffered from hypertension and dyslipidemia and he was in treatment with ARBs and statins. There had been no reports of previous cerebrovascular diseases.

During the procedure, a hemorrhagic shock took place and the patient was transfused with: 8 red blood cell units, $1500 \mathrm{cc}$ plasma and 4 grams of fibrinogen. $\mathrm{He}$ arrived in the intensive care unit hemodynamically stable and breathing on a venturi mask. The arterial gasometry values at the moment were: $\mathrm{pH} 7.20, \mathrm{pO}_{2}$ 90, $\mathrm{pCO}_{2} 45, \mathrm{HCO}_{3} 15, \mathrm{BE}-7$, lactate 8.5, $\mathrm{SpO}_{2} 96 \%$.

Acidosis was resolved within the next 24 hours. During the early postoperative phase, an acute renal failure took place with creatinine values of 2.8 and uremia of 120 . He also suffered a paralyticileus that was easily solved with IV prokinetics. Lactate levels stayed increased between 2.5 - 3, and hemoglobine was $10 \mathrm{gr} / \mathrm{dl}$.

Four days after surgery, the patient started to feel sleepy, hypothermic and developed an important cognitive impairment. His breathing rate was $50 \mathrm{bpm}$ and he didn't answer to easy orders. The arterial gasometry values with $4 \mathrm{lpm}$ nasal cannula support were:

$\mathrm{pH} 7.60, \mathrm{pO}_{2} 80 \mathrm{~mm} \mathrm{Hg} ; \mathrm{pCO}_{2} 16 \mathrm{~mm} \mathrm{Hg} ; \mathrm{HCO}_{3} 18 \mathrm{mmol} / \mathrm{L} ; \mathrm{BE}-10 \mathrm{mmol} / \mathrm{L}$; Lactate $4, \mathrm{SpO}_{2} 95 \%$.

A cranial CT-scan and MRI were performed along with an echocardiogram, chest X-ray, D-dimer and biochemical analysis. The results were normal with the exception of: creatinine 1.5, urea 47, decrease in phosphate levels 1.5 - 2.1 $\mathrm{mg} / \mathrm{DL}$ (normal values $2.5-4.5 \mathrm{mg} / \mathrm{DL}$ ), TSH $0.001 \mathrm{microUI} / \mathrm{mL}$ (nv 0.270 4.200) and T4 $0.1 \mathrm{ng} / \mathrm{dl}$ (nv 0.93 - 1.70).

$400 \mathrm{mg}$ IV Hydrocortisone was administered every 24 hours in order to avoid an acute adrenal crisis. In addition, a bolus of 300 microgr IV levothyroxine was given, followed by daily doses of 100 microgr to treat hypothyroidism.

A normal cognitive level, breathing pattern and lactate values were achieved within the next 24 hours.

\section{Discussion}

The pathophysiologic mechanism of $\mathrm{CNH}$ is unclear. It has been shown that in animal models, stimulation of the lateral parabrachial nucleus increased the respiratory rate.

Stimulation of respiratory control areas in thepons and medulla could explain 
$\mathrm{CNH}$ but it is not sufficient. It has been known that pontine respiratory group neurons modulate the respiratory rhythm. But animal models that disconnect the pontine respiratory group from the medulla have not resulted in $\mathrm{CNH}$.

Hyperlactatemia physiopathology as a cause of $\mathrm{CNH}$ is not well known. It is suspected that bicarbonate produced as a result of high lactic acid levels could cross blood brain barrier, resulting in metabolic alkalosis and increasing $\mathrm{CO}_{2}$ levels. As a result, the medullary chemoreceptors responsible for the development of hyperventilation are activated.

The start of a critically ill patient hypothyroidism in just 4 days is not common. Our patient did not need support of mechanical ventilation, benzodiazepines administration or other drug that could affect the thyroid axis. As analgesic drug we used IV fentanyl, this may have decreased the severity of $\mathrm{CNH}$ as the publications of Adachi YU et al. have suggested [13], it could be a good palliative treatment in $\mathrm{CNH}$ secondary to advanced tumours.

\section{Conclusions}

The diagnosis of $\mathrm{CNH}$ is dependent on the awareness of clinicians to investigate the etiology of tachypnea with or without electrolyte abnormalities. It is important to consider this option in our differential diagnosis when we confront a postsurgical patient after major surgery with poly transfusion and organ failure. Poly transfusion and organic failure with metabolic acidosis after major abdominal surgery is not uncommon, so we must be alert to clinical signs.

As a conclusion, we report Hypothyroidism Coma in critically ill patient showing up as $\mathrm{CNH}$, as an important postoperative complication in abdominal aortic aneurysm surgery. Probably this could be the first $\mathrm{CNH}$ case reported in this context at the time.

\section{References}

[1] Plum, F. and Swanson, A.G. (1959) Central Neurogenic Hyperventilation in Man. Archives of Neurology and Psychiatry, 81, 535-549. https://doi.org/10.1001/archneurpsyc.1959.02340170001001

[2] Gaviani, P., Gonzalez, R.G., Zhu, J.J., Batchelor, T.T. and Henson, J.W. (2005) Central Neurogenic Hyperventilation and Lactate Production in Brainstem Glioma. Neurology, 64, 166-167. https://doi.org/10.1212/01.WNL.0000148579.80486.F1

[3] Alkhachroum, A.M., Saeed, S., Kaur, J., Shams, T. and DeGeorgia, M.A. (2016) A Case of Neuro-Behcet's Disease Presenting with Central Neurogenic Hyperventilation. American Journal of Case Reports, 17, 154-159. https://doi.org/10.12659/AJCR.895382

[4] Tarulli, A.W., Lim, C., Bui, J.D., Saper, C.B. and Alexander, M.P. (2005) Central Hyperventilation: A Case Report and Discussion of Pathophysiology. Archives of Neurology, 62, 1632-1634. https://doi.org/10.12659/AJCR.895382

[5] Fabregas, N., López, A., Valero, R., Carrero, E., Caral, I. and Ferrer, E. (2000) Anesthetic Management of Surgical Neuroendoscopies: Usefulness of Monitoring the Pressure inside the Neuroendoscope. Journal of Neurosurgical Anesthesiology, 12, 21-28. https://doi.org/10.1097/00008506-200001000-00005

[6] Kim, G., Bae, J.H. and Lim, S.W. (2005) Hyperventilation Attack during Recovery 
from General Anesthesia: A Case Report. Korean Journal of Anesthesiology, 49, 735-738. https://doi.org/10.4097/kjae.2005.49.5.735

[7] Mizuno, J., Morita, S., Itou, Y., Honda, M., Momoeda, K. and Hanaoka, K. (2009) Hyperventilation Syndrome before Induction of and after Awakening from General Anesthesia. Masui, 58, 768-771.

[8] Sung, H.J., Sohn, J.T., Kim, J.G., Shin, I.W., Ok, S.H., Lee, H.K., et al. (2010) Acute Respiratory Alkalosis Occurring after Endoscopic Third Ventriculostomy: A Case Report. Korean Journal of Anesthesiology, 59, S194-S196.

https://doi.org/10.4097/kjae.2010.59.S.S194

[9] Lee, H.M., Shin, K.B., Kim, S.H. and Jee, D.L. (2012) An Acute Postoperative Intractable Hyperventilation after an Endoscopic Third Ventriculostomy. Journal of Korean Neurosurgical Society, 51, 173-176.

https://doi.org/10.3340/jkns.2012.51.3.173

[10] Carvalho, F.A., Maciel, R.O.H., Costa, E.L.V., Bernardino, T., Felizola, S.F.A. and Silva, G.S. (2011) Central Neurogenic Respiratory Failure: A Challenging Diagnosis. Case Reports in Neurology, 3, 75-81.

[11] Lee, H.M., Shin, K.B., Kim, S.H. and Jee, D.L. (2012) An Acute Postoperative Intractable Hyperventilation after an Endoscopic Third Ventriculostomy. Case Reports in Neurology, 51, 173-176. https://doi.org/10.3340/jkns.2012.51.3.173

[12] Merola, J., Liang, E., Hoskins, J., Balakrishnan, V. and Gan, P. (2016) Delayed Refractory Hyperventilation Following Endoscopic Third Ventriculostomy in a 5Year-Old Boy. Child s Nervous System, 32, 1731-1733. https://doi.org/10.1007/s00381-016-3062-x

[13] Adachi, Y.U., Sano, H., Doi, M. and Sato, S. (2007) Central Hyperventilation Treated with Intravenous Fentanyl Followed by Transdermal Application. Journal of Anesthesia, 21, 417-419. https://doi.org/10.1007/s00540-007-0526-x

\section{Scientific Research Publishing}

\section{Submit or recommend next manuscript to SCIRP and we will provide best} service for you:

Accepting pre-submission inquiries through Email, Facebook, LinkedIn, Twitter, etc. A wide selection of journals (inclusive of 9 subjects, more than 200 journals)

Providing 24-hour high-quality service

User-friendly online submission system

Fair and swift peer-review system

Efficient typesetting and proofreading procedure

Display of the result of downloads and visits, as well as the number of cited articles

Maximum dissemination of your research work

Submit your manuscript at: http://papersubmission.scirp.org/

Or contact ojanes@scirp.org 